\title{
Kemerovo Region's experience of implementing and promoting cluster initiatives in tourism industry
}

\author{
Sergey A. Vasyutin, Elena N. Deniskevich, \\ Oleg V.Kim, Roman V. Selezenev and \\ Konstantin V.Yumatov \\ Department of World History and Socio-Political Sciences \\ Kemerovo State University \\ Kemerovo, Russia
}

\author{
Nataliya S. Yakimova \\ Department of Foreign Languages \\ in Professional Communication \& \\ Department of Economic Theory and Public Administration \\ Kemerovo State University \\ Kemerovo, Russia \\ nataliyayakimova@mail.ru
}

\author{
Maksim I. Gavrilov \\ Regional Tourism Resource Centre \\ Kemerovo State University \\ Kemerovo, Russia
}

\begin{abstract}
The development of tourism in Kemerovo Region offers the professionals of the tourism industry the challenge of integrating the efforts of the key actors of the tourism industry the state and business. One of the methods of integration should be the cluster approach to the development of tourism. The article analyzes the implementation of cluster initiatives in tourism in the region. One of the key activities of the tourism cluster is information promotion of tourism resources and products. Modern technologies are used for solving this problem. Among the promising directions of tourism development in the region are the problems of branding and rebranding of Kemerovo region's tourist resources, and the tasks of marketing and advertising of tourist offers.
\end{abstract}

Keywords-tourism, Kemerovo region, cluster, promotion, marketing, online services

\section{INTRODUCTION}

Tourism is in many ways a unique and promising sector of the world economy. In the modern post-industrial information society, tourism allows solving e a wide range of important socio-economic problems, including those of expanded reproduction of labor resources, increasing employment, increasing welfare and improving the quality of life of the society, and ensuring social and cultural development of the population.

Russia has incalculable natural, climatic, socio-economic, cultural and historical tourist resources. On their basis, it is possible to create a unique tourism industry that meets modern requirements, to form competitive tourist products and successfully develop domestic and inbound tourism.

To date, there are a number of problems in the development of tourism that limit Russia's possibility of receiving tourists.
The main problems in the promotion of tourist services in Russia both in the domestic market and abroad are:

- poor infrastructure: insufficient number of hotels, recreation centres and other means of collective accommodation of tourists;

- the problem of transport accessibility of many territories and annual growth of tariffs for railway and air tickets;

- weak use of natural potential of all regions of Russia, first of all, in the territory of Siberia;

- insufficient development of new information and communication technologies in the tourism industry, which has a negative impact on advertising and information and image promotion of tourism products, resources, and destinations;

- insufficient level of public-private partnership, which hinders the implementation of many programs, projects and initiatives in tourism.

One of the modern tools for solving these problems should be the cluster approach in tourism, which involves the creation of tourist clusters in the regions, including Kemerovo Region (often called Kuzbass - after Kuznetsk Coal Basin, where most of the region's territory is located geographically).

\section{PROBLEM STATEMENT}

The article analyzes the effectiveness of the implementation of the strategic program of tourism development in the region. In particular, an attempt is made to assess the effectiveness of the implementation of two important goals of the strategic program - cluster initiatives in tourism, as well as information promotion of regional tourism. 
The introduction of cluster initiatives, that is, the creation of a number of tourist clusters, is a relatively new phenomenon in the development of the tourism industry in Russia. Initially, the term "cluster" expressed the theory of some economists that the successful development of the national economy depends on the local concentration of specialized industries [1].

The spokesman of this idea and the founder of the cluster approach in the economy is American economist M. Porter, who pointed out that "clusters are geographic concentrations of interconnected companies and institutions in a particular field, linked by commonalities and complementarities" [2]. Further analysis of the concept of "cluster" went around such meanings as "concentration", "territorial concentration": clusters were defined as sets of economic entities of related profile, interrelated and mutually reinforcing, closely spaced and contributing to the overall development and growth of one another's competitiveness [3].

At the same time, clusters are noted to serve as "growth points" of the domestic market for the entire economy of the state and in practice implement the idea of public-private partnership. In the most general form, the state provides for the organizational and financial support of initiatives from the business side, including subsidies for the costs of organizing cluster development centers in the regions of Russia [4].

At present, more than a hundred clusters in different spheres are listed in the register of the Russian Cluster Observatory [5]. The European experience shows a large spread of agro-industrial clusters [6]. Currently, the clustering processes cover more than $50 \%$ of the economies of the leading countries [7].

Over time, economists started trying to understand the ways of applying the cluster approach directly in tourism. In particular, S. Nordin was engaged in theoretical grounding of the tourism cluster and the possibility of applying this theory in practice. The author points out that the tourist cluster should include the following elements:

- $\quad$ tourist resources;

- internal agencies organizing and implementing the cluster concept;

- a set of campaigns that meet the tourist demand;

- environmentally friendly infrastructure;

- educational institutions providing training for the tourism industry;

- $\quad$ state bodies regulating and coordinating the activities of the cluster [8].

Thus, it can be seen that the cluster is a form of cooperation of three key actors of the tourism industry: business, government and the system of higher and vocational education and training. This proves the importance of the cluster approach, which should ensure effective cooperation and coordination of forces of the main participants of the tourism market.
A more detailed list of the required participants of the tourist cluster, which will allow the most effective use of its potential, needs to include the following groups of companies: business structures (usually small and medium enterprises), institutions of science and education (universities, colleges, and professional development and retraining institutions), cultural institutions (museums), financial organizations (banks, grant funds), public organizations (professional unions and associations), public authorities (federal, regional, and municipal) [9]. Accordingly, the "regional tourism cluster" means "a purposefully formed and geographically localized set of tourist attractions and enterprises of the tourism industry, infrastructure and related industries, between which there are stable vertical and horizontal links that ensure the improvement of the efficiency of enterprises and the creation of a competitive tourism product" [9].

When creating a tourism cluster, two principles are allowed: the formation of a cluster by industry or by territorial principle. In the end, the cluster concentrates the economic and tourist resources within a region, or within a separate branch of the tourist industry.

This approach implies certain dangers for the development of tourism. Firstly, too high territorial concentration of tourism enterprises is often negative. It can lead to excessive pressure on the natural ecosystem and to its destruction [10]. Secondly, if the cluster takes on exceptional commitments to the development of the tourism industry, concentrates the most effective resources in its hands, and fails for any reason, it can lead to a serious crisis in the tourism sector in the region. Thus, cluster initiatives require a very balanced and responsible approach to their implementation, hence the importance of understanding the existing experience.

Another important component of the successful functioning of the tourism industry is information support and promotion of regional tourism product in the media space, especially in the Internet.

The close relationship of this component with the activities of the cluster is obvious, as the latter should take on the task of image promotion of individual tourism resources and products, and the region as a whole.

The development trend of the modern society is such that in large cities we have almost universal access to the Internet. This, in turn, creates a situation where a huge layer of a variety of information is received from Internet resources. For example, people increasingly shop on the Internet rather than in stores, making there even everyday purchases online. In these conditions, new technological solutions and platforms through which digital marketing and online promotion of any product, including tourism products, will be implemented, are of particular importance. This will form a new and promising trend in the development of world tourism - "online tourism", or "Internet tourism".

What is "online tourism"? In fact, it is a type of tourism partially implemented in the Internet space. It is not about the fact that the tourist travels online, but about the fact that they plan and organize their journey through the Internet, using special services and programs. According to experts, more 
than $60 \%$ of travelers are looking for travel information on the Internet, and their number is constantly growing. There are many countries in the world where more than half of the trips are booked online - for example, China, Canada, the USA, and Western European countries [11].

The next step in the evolution of online tourism, which has already been partly made, is aggregation: combining all the possible tourist services in one resource or on one platform (aggregator). Currently, some online tour aggregators are already working in the tourism market: turagregator.ru "Yandex Travel" (travel.yandex.ru), "TravelStand" (travelstand.ru), etc.

Another obvious trend in the development of online tourism is a significant share of domestic tourism in the total amount of tourist interests. According to the portal TRN, in 2016, the reduction of organized outbound tourism in Russia amounted to $20 \%$, while the domestic organized tourism market grew by $18 \%$. The number of tour operators specializing in outbound tourism decreased from 2500 in 2014 to 750 in 2016, while the number of tour operators specializing in domestic tourism increased from 700 to 3700 . Among other things, it is connected with toughening of the legal requirements to the operators working in the sector of outbound tourism. An active consolidation of actors and services is taking place. Because of this, in 2016, the 20 largest companies accounted for $80 \%$ of sales [12].

This sets huge perspectives for the development of regional tourism, which we will focus on in this article.

\section{RESEARCH METHODS}

The authors of this article performed functional analysis of the activities of Kemerovo Region's authorities and the Tourism and recreation cluster of Kemerovo Region aimed at developing tourism in Kuzbass. The sociological method of interviewing the head and employees of the Center for cluster development of Kemerovo Region was also used. The content analysis of Kuzbass' tourist information resources and identification of the most effective forms of tourism services promotion were also carried out.

\section{RESULTS AND DISCUSSION}

In 2009, the authorities of Kemerovo Region passed a number of regional laws regulating the development of tourism in Kuzbass:

- Kemerovo Region Law "On tourist activity" No. 5OZ dated 06 February 2009;

- Kemerovo Region Law "On the development of domestic and incoming tourism" No. 88-OZ dated 13 July 2009; and

- Kemerovo Region Law "On the development of snow tourism in Kemerovo" No. 67-OZ dated 08 June 2009.

The laws set the goals and priorities of the state regulation of tourist activity in Kuzbass, and defined the regional authorities' powers in regulating tourism [13].
In March 2013, the "2025 Strategy for tourism development in Kuzbass" was adopted by the Decree of Kemerovo Region Administration Board. The Strategy set the goals of:

- $\quad$ forming a modern competitive tourism and recreation complex in Kemerovo region to provide a wide scope of opportunities for the growth of domestic and international tourist flows; and

- developing the tourist infrastructure to meet the population's need for high-quality rest [14].

One of the visible results of implementing the "2025 Strategy for tourism development in Kuzbass" was the establishment of two tourism and recreation clusters. In 2014, "Sheregesh Tourism and Recreation Cluster" was created in Kemerovo Region under Decree No. 1407 dated 18 December 2018 within the State program "Development of culture and tourism" for 2013-2020 in the Federal Target Program "Development of domestic and inbound tourism in the Russian Federation (2011 - 2018)" [15]. In 2014-2916, it received the funding of 1.565 billion rubles from the federal budget and 3.652 billion rubles of co-financing from non-budget sources [16].

In 2015, Tourism and recreation cluster of Kemerovo Region was created, and its development strategy was adopted, approved by the Decree of Kemerovo Region Administration Board No. 301-R dated 3 June 2015 [17]. The Cluster is funded by the Centre for cluster development within the framework of the program of the Ministry of economic development of the Russian Federation to support small and medium-sized enterprises. The implementation of the Cluster's activities is carried out on the basis of public-private partnership. The Cluster was officially established on 13 October 2015 after the strategic session, where was signed the agreement "On the formation of the Tourism and Recreation Cluster of Kemerovo Region" was signed. The agreement was signed by 33 participants of the strategic session (25 small and medium-sized business enterprises operating in the field of tourism, three municipal tourism organizations, two universities, heads of 2 departments of Kemerovo Region Administration and the CEO of "Kuzbass Technopark" stock company, on the basis of which the Centre for cluster development of Kemerovo Region was functioning). Kemerovo State University became the coordinator of the Cluster [18].

A comparative analysis of the tourism and recreation cluster of Kemerovo Region and large tourism clusters in the Russian Federation is provided in Table I. There are also tourist clusters created within the Federal target program "Development of domestic and inbound tourism in the Russian Federation (2011-2018)", including "Sheregesh Tourism and Recreation Cluster" in Kemerovo Region. To date, 23 projects are already being implemented under this Target Program in the country, and about 40 projects are being selected for inclusion in the Federal Target Program. The development of these tourism clusters involves public and private investment, so the clusters that have been established under this Target Program cannot be compared with the territorial clusters that are supported through the program of the Center for cluster 
development within the framework of the program of the Ministry of economic development of the Russian Federation, since the amount of funding between these programs is different.

The activities of the Tourism and Recreation Cluster of Kemerovo Region are funded by the Center for cluster development (since 1 January 1 2017, OOO Engineering Research and Development Centre "INNOTECH" has become the successor of the Center for cluster development) at the expense of the Federal subsidy allocated to the region under the program of the Ministry of economic development of the Russian Federation. Federal subsidies to the Cluster were distributed in the following spheres:

1) provision of marketing services (marketing research, development and promotion of umbrella brands, branding, positioning and promotion of new products of the enterprises members of the Cluster);

2) organization and conduct of training sessions, seminars with the involvement of third-party teachers and trainers for the staff of the enterprises - members of the Cluster;

3) development of business plans and feasibility studies for the members of the Cluster;

4) conduct of awareness campaigns for the members of the Cluster;

5) webinars and, round tables for the members of the Cluster;
6) organization of participation of the enterprises members of the Cluster in the Russian and foreign tourism exhibition sites.

In total, 11.1 million rubles were spent in 2015-2017 for the benefit of the members of the Cluster.

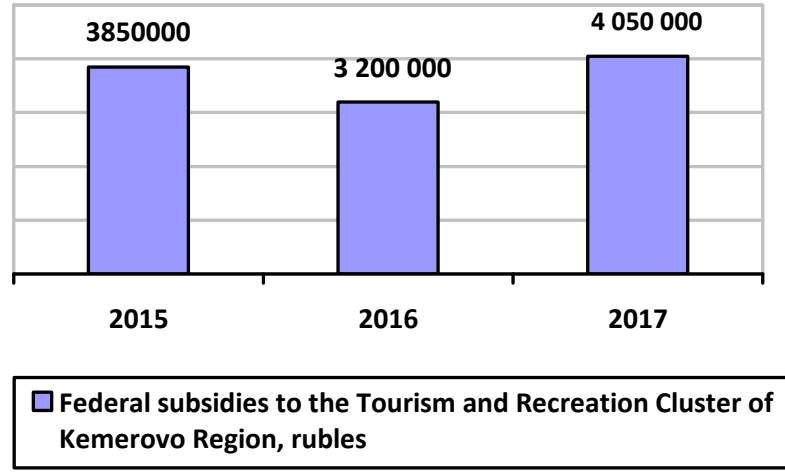

Fig. 1. Federal subsidies to the Tourism and Recreation Cluster of Kemerovo Region, 2015-2017.

The most significant projects implemented within the framework of Cluster's activities are presented in Table II. During the active work of the Council of the Cluster, informational, marketing, and financial support was provided to more than 50 small and medium-sized businesses.

TABLE I. COMPARATIVE ANALYSIS OF THE TOURISM AND RECREATION CLUSTER OF KEMEROVO REGION AND LARGE TOURISM CLUSTERS IN THE RUSSIAN FEDERATION

\begin{tabular}{|c|c|c|c|c|c|c|}
\hline Cluster & $\begin{array}{l}\text { District of } \\
\text { Russia }\end{array}$ & Key specialization & $\begin{array}{l}\text { Number } \\
\text { of parti- } \\
\text { cipants }\end{array}$ & $\begin{array}{c}\text { Year of } \\
\text { establish } \\
\text {-ment }\end{array}$ & $\begin{array}{l}\text { Stage of } \\
\text { develop- } \\
\text { ment }\end{array}$ & Status \\
\hline $\begin{array}{l}\text { Tourism Cluster } \\
\text { of Orel Region }\end{array}$ & $\begin{array}{c}\text { Central } \\
\text { Federal District }\end{array}$ & $\begin{array}{l}\text { Tourism (entertainment } \\
\text { and leisure industry, arts } \\
\text { and sports) }\end{array}$ & 48 & 2016 & initial & $\begin{array}{l}\text { Supported be the Centre for cluster development } \\
\text { within the framework of the program of the } \\
\text { Ministry of economic development of the } \\
\text { Russian Federation to support small and } \\
\text { medium-sized enterprises }\end{array}$ \\
\hline $\begin{array}{l}\text { Tourism Cluster } \\
\text { of Smolensk Region }\end{array}$ & $\begin{array}{c}\text { Central } \\
\text { Federal District }\end{array}$ & $\begin{array}{l}\text { Tourism (entertainment } \\
\text { and leisure industry, arts } \\
\text { and sports) }\end{array}$ & 30 & 2016 & initial & $\begin{array}{l}\text { Supported be the Centre for cluster development } \\
\text { within the framework of the program of the } \\
\text { Ministry of economic development of the } \\
\text { Russian Federation to support small and } \\
\text { medium-sized enterprises }\end{array}$ \\
\hline $\begin{array}{l}\text { Tourism Cluster } \\
\text { of Vologda Region }\end{array}$ & $\begin{array}{c}\text { North-West } \\
\text { Federal District }\end{array}$ & $\begin{array}{l}\text { Tourism (entertainment } \\
\text { and leisure industry, arts } \\
\text { and sports) }\end{array}$ & 74 & 2014 & initial & $\begin{array}{l}\text { Supported be the Centre for cluster development } \\
\text { within the framework of the program of the } \\
\text { Ministry of economic development of the } \\
\text { Russian Federation to support small and } \\
\text { medium-sized enterprises }\end{array}$ \\
\hline $\begin{array}{c}\text { Tourism and } \\
\text { Recreation Cluster } \\
\text { of Irkutsk Region }\end{array}$ & $\begin{array}{c}\text { Siberian } \\
\text { Federal District }\end{array}$ & $\begin{array}{l}\text { Tourism (entertainment } \\
\text { and leisure industry, arts } \\
\text { and sports) }\end{array}$ & 31 & 2017 & initial & $\begin{array}{l}\text { Supported be the Centre for cluster development } \\
\text { within the framework of the program of the } \\
\text { Ministry of economic development of the } \\
\text { Russian Federation to support small and } \\
\text { medium-sized enterprises }\end{array}$ \\
\hline $\begin{array}{c}\text { Tourism and } \\
\text { Recreation Cluster } \\
\text { of Kemerovo Region }\end{array}$ & $\begin{array}{c}\text { Siberian } \\
\text { Federal District }\end{array}$ & $\begin{array}{l}\text { Tourism (entertainment } \\
\text { and leisure industry, arts } \\
\text { and sports) }\end{array}$ & 98 & 2015 & initial & $\begin{array}{l}\text { Supported be the Centre for cluster development } \\
\text { within the framework of the program of the } \\
\text { Ministry of economic development of the } \\
\text { Russian Federation to support small and } \\
\text { medium-sized enterprises }\end{array}$ \\
\hline
\end{tabular}


TABLE II. SIGNIFICANT PROJECTS OF THE TOURISM AND RECREATION CLUSTER OF KEMEROVO REGION IN 2015 -2017.

\begin{tabular}{|c|c|}
\hline Project & Description \\
\hline TV Project: "Kuzbass: White and Furry" & Creating common television information content for tourism product promotion \\
\hline $\begin{array}{l}\text { Business plan for the project of the river } \\
\text { route "Stone Epos of Pritomye" }\end{array}$ & $\begin{array}{l}\text { Launching weekend ( } 3 \text { days / } 2 \text { nights) and single-day tours along the new route "Stone Epos of Pritomye" } \\
\text { (Kemerovo - Tomskaya Pisanitsa Museum-Reserve - Novoromanovo Pisanitsa - Tomskaya Pisanitsa } \\
\text { Museum-Reserve - Kemerovo). }\end{array}$ \\
\hline $\begin{array}{l}\text { Professional development programs for } \\
\text { tour guides and tourism staff }\end{array}$ & $\begin{array}{l}\text { Improving the practical skills of Kemerovo Region tourism industry staff: developing tour guides' English } \\
\text { language skills using prominent European teaching methodologies: PBL approach and CLIL [19] }\end{array}$ \\
\hline Promoting Podnebesnye Zubya destination & $\begin{array}{l}\text { Developing the road-map for Podnebesnye Zubya development and the destination brand. (In } 2017 \text { the } \\
\text { local souvenirs were branded, and in future the brand will be used in designing the Podnebesnye Zubya } \\
\text { hotel }\end{array}$ \\
\hline $\begin{array}{l}\text { Brand book of Kuzbass tourism } \\
\text { destinations }\end{array}$ & Developing the brand book of Kuzbass tourism destinations ( 2000 copies published) \\
\hline Familiarization tours & $\begin{array}{l}\text { Organizing } 3 \text { familiarization tours for the tourism industry and mass media representatives aimed at } \\
\text { promoting Kuzbass tourism routes: } \\
\text { 1) tour of Podnebesnye Zubya; } \\
\text { 2) "Stone Epos of Pritomye" tour; } \\
\text { 3) tour dedicated to the } 70^{\text {th }} \text { anniversary of celebrating Miners' Day }\end{array}$ \\
\hline $\begin{array}{l}\text { Business plan for building a tourist } \\
\text { complex at the eco-farm in Verkh-Tesh, } \\
\text { Kaltan District }\end{array}$ & $\begin{array}{l}\text { Developing the business plan for building a tourist complex at the eco-farm in Verkh-Tesh, Kaltan District } \\
\text { for future implementation of the project }\end{array}$ \\
\hline Participation in exhibitions and fairs & $\begin{array}{l}\text { Promoting the region's tourism potential and increasing the incoming tourism flow to the region through } \\
\text { participation in the leading tourism industry exhibitions in Russia: } \\
\text { 1) OTDYKH LEISURE International trade fair for travel \& tourism (Moscow); } \\
\text { 2) business meetings at Workshop STI (Omsk, Novosibirsk, Krasnoyarsk); } \\
\text { 3) Moscow International Travel and Toursim Exhibition «MITT»; } \\
\text { 4) Russian National Online Fair for tourism industry professionals "Znay Nashe" at nashe.profi.travel }\end{array}$ \\
\hline
\end{tabular}

As part of the implementation of these projects, in addition to Federal funding, additional funding was attracted from tourist companies who ordered some services. The creation of joint cluster projects allowed involving into their implementation as customers of services not only the members of the Cluster, but also the enterprises that were not members of the Cluster in the status contractors. This allowed creating a multiplier effect of their inclusion in the added value chain of the cluster and the volume of production, as well as increasing the number of small and medium-sized enterprises who benefited from the Cluster activities. The fact that new members are constantly joining the Cluster is significant as well: in 2015-2017, the number of members of the Cluster increased from 33 to 98 . The geography of the cluster is extended to the entire territory of Kemerovo Region.

These facts may indicate the interest of small and mediumsized businesses in the tourism and recreational complex of Kemerovo Region in the Cluster, in which they see a tool to improve the competitiveness of their enterprises and to expand the range of tourist services in the region.

An important aspect of tourism development in Kuzbass is information promotion and advertising of the region's recreational potential. This task, in turn, is closely related to the problem of creating tourist brands. We need an attractive, recognizable image that reflects regional specifics. In the mass perception, Kuzbass is associated with the coal industry, which has even given the region its name (Kuzbass is the shortening for "Kuznetsk coal basin"). Positive branding of the destination involves a focus on non-industrial aspects such as Siberian health, ecology, ethnic culture, sports tourism. Similar ideas were successfully implemented in the neighboring regions of Altai Krai (now branded with the motto "In Altai Krai everything is real") and Altai Republic (branded with the motto "Altai heals").

The coal theme can be presented in a more humanitarian context, for example, as "Kuzbass, giving energy and light, and bringing heat". The undisclosed mysteries and the unknown unique attractions of Kuzbass have become a symbolic theme of the brand book of the Tourism and Recreation Cluster of Kemerovo Region. Its main logo, symbolizing the search scanner and fitted in a circle, forms stylized letters "K" and "O" (for Kemerovskaya Oblast' Kemerovo Region), and stands for "territory of discoveries".

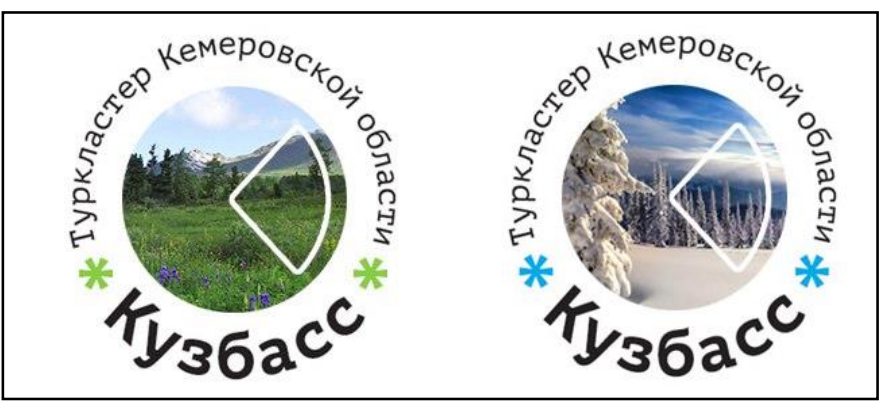

Fig. 2. Logos of Tourism and Recreation Cluster of Kemerovo Region.

Developing a relevant and attractive brand is an important condition for the success of tourism policy. The "2025 Strategy for tourism development in Kuzbass" offers various approaches and tools to address this problem. Among them, the organization of advertising info tours, information support for event tourism and even events to promote "Kuzbass Yeti" 
- the brand of Sheregesh ski resort, [14: 68-71]. In order to attract public attention to the variety of tourist attractions, the regional contest "Seven wonders of Kuzbass" was held in 2011. As the result, the list of Kuzbass' major sites was determined: Podnebesnye Zubya, Tomskaya Pisanitsa, Kuznetsk fortress, Azasskaya cave, Golden Shoria sculpture, the town of Mariinsk as an open-sky museum, and the monument "In memory of the miners of Kuzbass".

In 2012, director Nikolai Savosin produced the 12-episode film "Unknown Kuzbass"" with Nikolay Valuev as the main host for "Moy Gorod" TV channel. The film was intended for a wide audience and was purchased by the central TV channel "Rossiya" ("Russia"). The main attention was paid to the Shor National Park, ethnography, and cultural heritage of Kemerovo Region. In 2015-2016, director Alexey Stoyanov produced the film series "Kuzbass, white and fluffy" for "CTC Kuzbass" channel. The series presented a wide panorama of winter recreation, entertainment and winter sports.

But the main task of information policy in the field of commercial tourism must be creating an integrated information environment that would allow for operational and direct communication between producers and consumers of tourism services.

Currently, there are quite a few not related sources of information about tourist sites and vacation destinations in the region: 1) information portals with the audience of national and international coverage (RussiaTravel, Visit-Kuzbass.ru, Gesh.Info, etc.) providing descriptions of the major destinations; 2) digital TV channels ("Moy Gorod" ("My city"), "Nasha Sibir"," ("Our Siberia"), "Sdelano v Kuzbasse" ("Made in Kuzbass") forming the visual image and mostly focused on natural objects; 3) websites of tour operators in Siberia (INESTour, Fansport, Beliy Kamen', Meridian, etc.) promoting regional tours and recreation programs; 4) social network groups and travelers' blogs forming a separate category.

It should be noted that in Sheregesh ski resort local private tourist information service has developed much earlier than in the regional centre. The tourist information center and website in Gornaya Shoria appeared in 2008, due to the logic and needs of regional business. Its activities are supported by the local tourist business entities. The information and entertainment portal Gesh.Info offers tourists comprehensive information about travel and recreation in Sheregesh, including transport and accommodation services, equipment rental, lifts maintained by different operators, webcasts, booking and payment for a variety of services.

In 2015, the information portal on tourism in Kuzbass Visit-Kuzbass.ru was launched [20]. Since that time, it has constantly been filled with content. However, at the moment there is an obvious need for changing the strategic approaches to the development of information support for regional tourism, seriously updating this resource and transferring it to a fundamentally new technological platform.

In 2017, within the framework of a project of the Tourism and Recreation Cluster of Kemerovo Region and as the result of the cooperation between the Regional Tourism Resource
Center (Kemerovo State University), the Tourist Information Centre of Kuzbass and the Agency of Internet marketing "Make" a project of major technological changes to the portal Visit-Kuzbass.ru was developed

In fact, the project is aimed at creating a fundamentally new technological platform in the region, an online service system that will only partially use the information resources of the old website. It is aimed at implementing the principles of online tourism and aggregation, since the authors plan to create a resource that will become an online assistant for users to plan and organize their holidays in the region.

The project assumes that the service Visit-Kuzbass.ru must occupy a niche in the market of Tours\&Activities - an online service to search for excursions and guides. The market of Tours\&Activities is estimated at more than $\$ 100$ billion, and it is expected to reach $\$ 183$ billion by 2020 [21]. The online market is in the initial stage of its development and has not been occupied yet.

Thus, this resource should not become a competitor for the regional tour operators, but should be a symbol and an instrument of their mutually beneficial cooperation. It is also planned not to compete, which in modern conditions does not make sense, but to integrate with the existing and popular resources for booking tickets, hotels, etc.

In the end, the main result of introducing an online aggregator should be the increase in the size of domestic tourist flow in the region. Another important task is advertising, information and image promotion of Kemerovo Region as an innovative and favorable region for the development of tourism. The importance of the latter is highlighted in the "2025 Strategy for tourism development in Kuzbass".

\section{CONCLUSION}

Thus, the cluster approach to the development of tourism in Kemerovo Region has allowed implementing a number of activities and projects aimed at improving the competitiveness of the tourism industry and expanding the range of tourist services in the region. The dynamics of the increase in the number of cluster members and applications for new projects are indicators of the interest of small and medium-sized businesses working in Kuzbass' tourism and recreational complex in the Cluster. At the same time, the Tourist and Recreational Cluster of Kemerovo Region is relatively young and in many ways its activities are a matter of prospects. One of such promising projects is the formation of a new information space of regional tourism in Kuzbass. There is a modern technological solution of this problem: the creation of an online aggregator that can integrate search queries of users and the information environment of the tourism industry. The main directions are obvious-advertising of natural recreation, active recreation in the Siberian interior, adapted for mobile applications. On the other hand, the conceptual and creative solution to this problem meets serious obstacles of different levels. They are associated with the lack of unified and generally accepted approaches to branding and promotion of tourism resources. Important obstacles are insufficient funding 
and lack of large companies' regional experience of branding tourist destinations.

If this project is implemented, the emergence of such large and modern service in the Kuzbass tourist market will fundamentally change the possibility of expanded sales of regional tourist products and will bring the development of tourism in Kemerovo Region to a new level.

\section{References}

[1] E. S. Samostrokova, "Classification of clusters of enterprises", in Young Scientist, no.1, vol.1, P. 141-143, 2012. URL: https://moluch.ru/ archive/36/4094/.

[2] M.E. Porter, "Clusters and the New Economics of Competition", in Harvard Business Review, Vol. 76, Issue 6, Nov/Dec 1998. URL: https://hbr.org/1998/11/clusters-and-the-new-economics-of-competition

[3] S. N. Kotlyarova, "Practice of cluster formation in the regions of Russia", in Regional Economy: Theory and Practice, no. 24, 2012, pp. 29-39.

[4] V. Arsenov, "Major prerequisites for the formation of clusters", in Science and, vol. 11, no. 165, 2016, pp. 37-41. URL: https://cyberleninka.ru/article/n/osnovnye-predposylki-formirovaniyaklasterov

[5] Website of Russian Cluster Observatory, 2018. URL: http://cluster.hse.ru

[6] Website of European Cluster Observatory, 2018. URL: http://www.clusterobservatory.eu/

[7] E. S. Tsepilova and O I. Belyaeva, "Prospects of the regional integration policy based on cluster formation", in Science Journal of Volgograd State University. Global economic system, no. 3 (40), 2017, pp. 99-108.

[8] Sara Nordin, Tourism Clustering \& Innovation - Paths to Economic Growth \& Development. European Tourism Research Institute (ETOUR), Publication 14, 2003

[9] S. V. Valeeva, "Development of the cluster approach concept in tourism", in National Interests: Priorities and Security, no. 1 (334), pp. 116-130, 2016.

[10] T. P. Levchenko, K. K. Kulyan, and M. K. Kulyan, "Cluster Approach to Steady Development of Travel Destinations", Izvestiya Sochi State University, no. 2(20), pp. 67-72, 2012.

[11] Online Tourism: A new format of travel. Retrieved from the websitr of Daily Money Expert Publishing House. URL: http://dailymoneyexpert.ru/how-to-spend/2015/11/20/onlajn-turizmputeshestviya-novogo-formata-3676.html

[12] Tourism in 16/2017: results and perspectives, published 23.12.2016. Retrieved from the portal TRN (Travel Russian News), URL: http://www.trn-news.ru/articles/49403

[13] Legal Acts Regulating the Sphere of tourism. Retrieved from the website of Kemerovo Region Department of Youth Policy and Sport, 2009. URL: http://www.dmps-kuzbass.ru/tourism/legislation/

[14] 2025 Strategy for tourism development in Kuzbass. Adopted by the Decree of Kemerovo Region Administration Board № 194-p dated 1.03.2013. Retrieved from the website of Kemerovo Region Administration, 2013. URL: https://ako.ru/upload/medialibrary/14e/ Strategija_razvitija_turizma_v_Kemerovskoj_oblasti_do_2025_goda_ot _01.03.2013_goda_№194-r(6).doc

[15] Decree No. 1407 dated 18.12.2014 within the State program "Development of culture and tourism" for 2013-2020 in the Federal Target Program "Development of domestic and inbound tourism in the Russian Federation (2011 - 2018)". Retrieved from the website of the informational and legal portal "Garant.ru". URL: http://base.garant.ru/ 70830634/\#friends

[16] Atlas of investment projects in the sphere of tourism implemented in the subjects of the Russian Federation, 2017. Retrieved from RussiaTourism Official Website. URL: https://www.russiatourism.ru/urgent/13886/

[17] 2025 Strategy for the development of Tourism and Recreation Cluster of Kemerovo Region, 2015. Retrieved from the Electronoc Fund of Documents on Legal and Technical Norms. URL: http://docs.cntd.ru/document/ 428564318

[18] H. Halkier, D. K. Müller, C. Anastasiadou, L. Kiriyanova, N. Goncharova, F. Kagan et al. Tourist destination dynamics in Russia. Tourism development and public-private partnership in four nonmetropolitan destinations. Aalborg: Department of Culture and Global Studies, Aalborg University, 2016.

[19] K. V. Yumatov, L. G. Kiriyanova, N. S. Yakimova, N. A. Zaitseva, A. A. Larionova, and N. M. Korsunova. "Problem-Based Learning Methods for Training Staff for Tourism and Hospitality Clusters", in Eurasian J Anal Chem, vol. 12(A Multidisciplinary Approach to science 5b), pp.803-812, 2017. DOI: https://doi.org/10.12973/ejac.2017.00212a

[20] The website of the Tourism and Recreation Cluster of Kemerovo, 2018. URL: http://visit-kuzbass.ru/ru/

[21] A. Jong, Travel's Tours \& Activities Market to Reach $\$ 183$ Billion by 2020, 2017. URL: https://www.phocuswright.com/ TravelResearch/Research-Updates/2017/Travels-Tours-and-Activities-Marketto-Reach-US183B-by-2020 